\title{
TEORI EKONOMI DAVID RICARDO, THOMAS MALTHUS, DAN JB. SAY
}

\author{
Rizka Amaliah S / 90100118102
}

Ekonomi klasik secara umum dianggap sebagai aliran modern pertama dalam sejarah pemikiran ekonomi. Mazhab klasik muncul pada akhir abad 18 dan awal abad 19 yaitu masa revolusi industry. tokoh penganut nazhab klasik yang terkenal yaitu Adam Smith, dimana karya monumentalnya yang terbit pada tahun 1776 dianggap sebagai tonggak sejarah lahirnya ekonomi modern. Pemikir dan pengembang utama aliran ini antara lain adalah Adam Smith, Jean-Baptiste Say, David Ricardo, Thomas

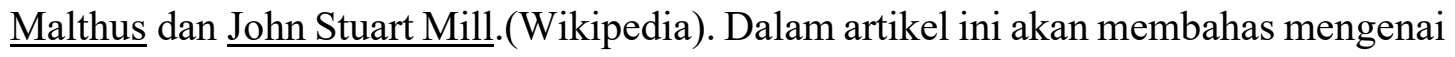
teori ekonomi David Ricardo, Thomas Malthus, JB. Say.

\section{Teori Ekonomi David Ricardo}

David Ricardo sebagai ahli ekonomi politik Inggris yang lahir di London pada tahun 1772. David Ricardo pada tahun 1817 mempublikasikan karya nya dalam bentuk buku "On the Principle of Political Economiy and Taxation " (Faruq dan Mulyanto, 2017). Pemekiran ekonomi David Ricardo yang terkenal yaitu teori komperatif . teori ini mengemukakan bahwa negara dapat tetap melakukan perdagangan walaupun salah satu negara tidak memiliki keunggulan absolut atau dengan kata lain memiliki kerugian absolut terhadap negara lain dalam memproduksi dua barang. Perdagangan akan tetap menguntungkan apabila negara yang mengalami kerugian absolut menspesialisasikan produksinya pada barang yang memiliki kerugian absolut lebih kecil.(I'id Badry : 2013)

Secara umum David Ricardo mendasarkan teorinya pada sejumlah asumsi yang disederhanakan, yaitu:

a. hanya terdapat dua negara dan dua barang

b. perdagangan bersifat bebas 
c. terdapat mobilitas tenaga kerja yang sempurna di dalam negara namun tidak ada mobilitas antara dua negara

d. biaya produksi konstan

e. tidak ada biaya transportasi

f. tidak ada perubahan teknologi.

\section{Teori Ekonomi Thomas Malthus}

Thomas Malthus dilahirkan pada tanggal 13 Februari 1766 di Surrey, Inggris. Malthus merupakan orang pertama yang berhasil mengembangkan suatu teori kependudukan yang komprehensif dan dan konsisten dalam kaitannya dengan kondisi Prekonomi. Ide tentang kependudukan dituangkannya ke dalam bukunya yang berjudul 'Essay on the Principle of Population' yang terbit pertama kali pada tahun 1798 (Subair : 2015). Selain itu, Malthus juga menghabiskan sisa hidupnya untuk mempertahankan dan merevisi tesis overpopulasinya. Dia juga menulis banyak buku, seperti The Principles of Political Eonomy pada tahun 1820 (Faruq and Mulyanto, 2017).

Pemikiran ekonomi Thomas Malthus terkait dengan teori asuransi, Tho-mas Robert Maltus menjelaskan bahwa Pada reasuransi konvensional, kontrak antara kedua belah pihak dimana insurer memberlaku-kan diri sebagai pihak yang dijamin memba-yarkan premi asuransi kepada pihak perusa-haan reasuransi. Terjadi transfer risiko dari reasuransi kepada insurer.

Thomas Robert Maltus juga me-njelaskan bahwa dalam hal asuransi konvensional tercermin adanya peran dan fungsi individu untuk saling membangtu secara kolektif dalam hal pertangungan. Pandangan ini dikenal dengan istilah teori fungsional ekonomi. (Yusuf : 2014)

Contoh Pemikiran Malthus yang relevan dengan perekonomian di Indonesia adalah Pengendalian jumlah penduduk untuk menghindari terjadinya edakan penduduk dengan adanya program pemerintah tentang Keluarga Berencana (KB) sebagai gerakan 
nasional dengan cara mengenalkan tujuan-tujaun program KB melalui jalur pendidikan, menepis anggapan yang salah

tentang banyak anak banyak rezeki. (Faruq and Mulyanto, 2017).

\section{Teori Ekonomi BJ SAY / JEAN BAPTISTE SAY}

BJ Say berasal dari Perancis, yang sangatmemuja Adam Smith. Say berjasa dalam melakukan kodifikasi pemikiran Smith dan dirangkum dalam bukunya Traite d'Economie Politique pada tahun 1803, dan mendukung faham laissez faire (wikipedia.org).Kontribusi Say yang paling besar pada mazhab klasik adalah 'setiap penawaran akan menciptakan sendiri permintaannya' atau dikenal dengan supply creates its own demand. Pendapat ini sering disebut dengan Say‘s Law. Hukum Say didasarkan pada asumsi bahwa nilai produksi selalu sama dengan pendapatan. Dengan demikian, dalam keadaan seimbang, produksi cenderung menciptakan permintaannya sendiri (Deliarnov, 2014).

Dalam bukunya,Say menyerang doktrin kelangkaan uang ini dengan menyatakan bahwa yang menciptakan permintaan bukan uang. Uang hanyalah sebagai alat tukar, yang menciptakan permintaan adalah produk barang dan jasa. Dan menurutnya penyebab riil dari depresi ekonomi bukanlah uang namun kurangnya penjulan oleh petani, pengusaha pabrik dan produsen barang. Penjualan tidak bisa dikatakan sepi karena uang langka namun karena penawaran barang dan jasa itu menurun. Yang memfasilitasi penjualan bukanlah melimpahnya uang namun karena banyaknya penawaran akan barang dan jasa. (Umar, 2012)

Contoh pemikiran ekonomi Pemikiran Say yang relevan dengan perekonomian di Indonesia adalah :Berkembangnya jiwa entrepreneur di kalangan masyarakat untuk meningkatkan perekonomian. Karena dengan banyaknya entrepeneur akan membuka lapangan kerja baru, sehingga pengangguran dapat dikurangi. Entrepeneur yang 
tangguh akan menjaga stabilitas ekonomi suatu negara. Kurikulum pendidikan di Indonesia pun memuat materi yang akan menunjang munculnya entrepreneur muda di Indonesia. Kurikulum tersebut dimulai dari pendidikan dasar hingga pendidikan tinggi.( (Faruq and Mulyanto, 2017). 


\section{DAFTAR PUSTAKA}

Subair, S (2018). Relevansi Teori Mlthus Dalam Diskusi Kursus Kependudukan Kontemporer. DIALEKTIKA. 9(2).

Yusup, D. K. (2014). PERBANDINGAN TEORI ASURANSI: STUDI PERBANDINGAN TEORI EKONOMI TAQIYYUDDÎN AL-NABANI DAN THOMAS ROBERT MALTUS. Asy-Syari'ah, 16(2), 145-158.

Faruq, U. A., \& Mulyanto, E. Sejarah Teori-Teori Ekonomi. Banten: Unpam Press, 2017.

Deliarnov. 2014. Perkembangan Pemikiran Ekonomi. Edisi Ketiga. Jakarta: Rajawali Pers.

Yusuo, DKK (2014). Perbandingan Teori Asuransi : Studi Perbandingan Teori Ekonomi Taqiyyuddin Al- Nabani Dan Thomas Robert Maltus. Asy- Syaria;ah $16(2), 145-158$.

I'id Badry Sa'idy (2013). ANALISIS DAYA SAING KOMODITAS TEKSTIL DAN PRODUK TEKSTIL INDONESIA DI AMERIKA SERIKAT 2(4), 269-276.

https://id.wikipedia.org/wiki/Ekonomi_klasik diakses pada 6 Mei 2021

Umar. 2012 Jean-Baptiste Say, Pengembang Model klasik Smith (padasuatuhari.com) diakses pada 6 Mei 2021 